\title{
JOGOS DE LINGUAGEM RELIGIOSOS? reflexões a partir dos escritos de Wittgenstein sobre religiosidade
}

\section{Religious language games? reflections from Wittgenstein's writings about religion}

\author{
Marciano Adilio Spica \\ Doutorando em Filosofia pela Universidade Federal de Santa Catarina (UFSC), Florianópolis, \\ SC - Brasil, e-mail: mspica@bol.com.br
}

\begin{abstract}
Resumo
O presente trabalho mostra a possibilidade da existência de jogos de linguagem religiosos, a partir dos escritos sobre religiosidade presentes na obra de Wittgenstein. Tentamos mostrar o que diferencia a linguagem religiosa de uma linguagem sem sentido, como, por exemplo, a linguagem metafísica, e também o que a diferencia de linguagens empíricas, como por exemplo a linguagem da ciência. Posteriormente, analisamos como deveríamos entender a linguagem religiosa para não cairmos em confusão quando com ela nos deparamos.
\end{abstract}

Palavras-chave: Wittgenstein. Religião. Jogo de linguagem. Gramática. 


\section{Abstract}

This work shows the possibility of the existence of religious language games, from the writings on religion in the work of Wittgenstein. We try to show what differentiates the religious language of the meaningless language, such as metaphysic, and also as distinct from empirical languages such as the language of science. Later, discussing how we should understand the language of religion for ourselves not in trouble with her when we face.

Keywords: Wittgenstein. Religion. Language game. Grammar.

\section{INTRODUÇÃO}

Wittgenstein, em muitas passagens de sua obra pós-tractatus, demonstra interesse em entender a religião e chega ao ponto de dizer que seu pensamento tem a forma do pensamento religioso. Porém, apesar dessas anotações, tal autor nunca chegou a afirmar a existência de jogos de linguagem religiosos, deixando espaço para que muitas interpretações controversas surgissem sobre este tema. O objetivo de nosso trabalho é tomar parte nessas discussões e mostrar a possibilidade de defenderemos a existência de jogos de linguagens religiosos. Entendemos que o filósofo em questão mostra a impossibilidade de se entender a linguagem religiosa como uma linguagem empírica e, por consequência, a impossibilidade dela se guiar pelas mesmas regras de uma linguagem científica. As crenças religiosas independem de provas e justificações e, portanto, crer em um fato científico tem um caráter diverso de crer em Deus, por exemplo. Enquanto a primeira se caracteriza por uma crença que busca por provas e justificações, a última se basta na própria crença. Por outro lado, a linguagem religiosa não é uma linguagem metafísica, por estar ligada a atividades dentro de uma forma de vida. Para cumprir nosso caminho, faremos uma breve análise de alguns apontamentos sobre a religião feitas por Wittgenstein, principalmente os que se encontram em Cultura e Valor e nos Observaciones a La Rama Dorada de Frazer. 


\section{A possibilidade de jogos de linguagem religiosos}

Nas Observaciones a La Rama Dorada de Frazer, Wittgenstein critica a visão que o antropólogo em questão tem das religiões primitivas. Wittgenstein entende que o problema de Frazer é ter entendido as religiões primitivas como um erro. E tal problema surge justamente deste não ter observado a religião e os ritos de acordo com a visão que as próprias crenças tinham, mas as ter estudado sob o olhar de um cristão inglês. Por um lado, ele teria entendido as religiões primitivas em comparação ao cristianismo de sua época, por outro, ele estaria simplificando o significado dos ritos religiosos ao estudá-los sob a ótica das leis da ciência natural. O filósofo austríaco se pergunta até que ponto poderíamos entender que santo Agostinho ou Buda ou outro qualquer estavam errados ao expressar uma determinada religiosidade e conclui: "Nenhum deles estava em erro a não ser quando criaram uma teoria." (WITTGENSTEIN, 1992, p. 50).

Essa frase é ilustrativa para mostrar que a religião não é entendida por Wittgenstein como uma teoria e nem deve ser entendida dessa forma. Mas é justamente isso o que faz o antropólogo Frazer. Ele olha os ritos religiosos, buscando encontrar neles sempre uma teoria que legitime tais mitos. O pressuposto parece errado e fica mais errado ainda quando o antropólogo em questão coloca teorias iguais ou muito próximas a teorias das ciências naturais. A crítica de Wittgenstein a Frazer é o exemplo claro de que para tal autor não devemos incorrer no erro de tentar compreender todas as atividades linguísticas de uma única forma. Sua proposta é justamente de olharmos para a variedade da linguagem. Ao não compreendermos a variedade de expressões, nos mantemos numa única forma de ver o mundo e a linguagem, estreitamos nossa visão por não entendermos que há muito mais conceitos do que aqueles que estamos habituados a usar e que esses conceitos podem ser totalmente diferentes dos nossos, apesar de usarem, às vezes, as mesmas palavras que as nossas. É isso que faz Wittgenstein exclamar uma espécie de desabafo diante da leitura que Frazer faz das religiões primitivas:

Que estreita é a vida do espírito para Frazer! E conseqüentemente: Que incapacidade para compreender uma vida que não seja a de um inglês de seu tempo! Frazer não pode imaginar um sacerdote que não seja, no fundo, como um pároco inglês de nossos dias com toda a sua imbecilidade e mediocridade (WITTGENSTEIN, 1992, p. 57). 
Tal desabafo se explica por Frazer estar totalmente envolvido numa forma de ver o mundo, que é a forma de sua época. $\mathrm{O}$ antropólogo em questão está dogmaticamente envolvido na linguagem científica ocidental do século XX e não consegue sair dela e, ao não conseguir ir para além, generaliza-a a todas as linguagens possíveis. Como bem expressa Moreno:

Frazer não estaria cometendo apenas um erro teórico; seu erro foi principalmente incorrer na generalização de determinada visão de mundo, ou melhor, estaria atribuindo, de maneira dogmática, ainda que inadvertidamente, o modelo de explicação científica do século XX, explicação através de hipóteses e causas, aos indivíduos das comunidades cujos rituais descreve e pretende explicar. O erro teórico consiste apenas em supor que explicações causais possam esclarecer o sentido de comportamentos ritualístico, quando, na verdade, esse tipo de explicação fornece somente ligações empíricas. Erro mais grave e profundo consiste em atribuir uma falsa ciência a comunidades em que hábitos ritualísticos não visam, segundo Wittgenstein, explicar processos naturais através de causas, mas exprimir valores de sua cultura. Erro profundo, porque atribui valores e hábitos de uma sociedade aos indivíduos de outra sociedade, cujos valores e hábitos pretende compreender. Confusão gramatical que tem conseqüências teóricas e éticas no trabalho do antropólogo (MORENO, 2005, p. 275-276).

Frazer vê os ritos com os olhos da ciência moderna e então chega à conclusão que os ritos são falhos e ingênuos, pois eles não chegam aos resultados que a ciência chega. Mas não é essa a função do rito, ele não é uma explicação metodológica de causas e efeitos, mas expressão de uma forma de ver o mundo e também os fenômenos naturais.

O que Frazer precisa, e nós também, é fazer uma terapia gramatical que cure essa busca por generalidade que torna o indivíduo dogmático e atrapalha a visão correta dos fenômenos humanos e naturais. Não podemos sobrepor a nossa linguagem a todas as linguagens possíveis. Isso é um erro grave que tem como resultado principal um entendimento totalmente errôneo daquilo que buscamos compreender. $\mathrm{O}$ erro do filósofo que faz isso é o erro de superficialidade, ou seja, ele não vai ao fundo das questões linguísticas, mas fica na superfície onde se reflete a imagem dele mesmo. É como se estivéssemos à beira de um rio e, ao olhar para a água, víssemos nossa imagem refletida e disséssemos que no rio vivem seres humanos como nós. É preciso ir além da superficialidade e ver a diversidade de coisas que o rio da linguagem nos apresenta. 
Frazer projeta sua cultura na cultura alheia e assim chega a conclusões que são totalmente equivocadas. Ora, entender que ritos têm a mesma natureza linguística que a ciência ou que todos eles têm a mesma natureza é, na visão de Wittgenstein, ingenuidade. É diante disso que ele dirá que,

Frazer é muito mais selvagem que a maioria dos selvagens, posto que estes não estariam tão afastados da compreensão de algo espiritual como está um inglês do século XX. Suas explicações dos costumes primitivos são muito mais superficiais que o sentido de tais costumes (WITTGENSTEIN, 1992, p. 65).

Essa nossa digressão sobre as anotações de Wittgenstein sobre La Rama Dorada teve como objetivo mostrar que é necessário pensarmos na variedade de jogos e também que parece possível a existência de jogos de linguagem religiosos e que eles são profundos e enraizados em costumes e práticas que devem ser levadas em conta. Se não fizermos isso, corremos o risco de condenar diferentes visões das nossas, simplesmente pelo fato de nos colocarmos como os únicos donos da verdade, uma verdade generalizada. Com isso, fica claro porque entendemos ser necessário esclarecer a existência e gramática dos jogos de linguagem religiosos. Mas será isso possível?

Wittgenstein nunca expressou explicitamente a existência de jogos de linguagem religiosos e, mais do que isso, nunca escreveu uma obra falando explicitamente sobre tal tema. O que temos em mãos são anotações presentes em seus diários e, muitas vezes, apenas anotações de seus alunos que assistiram aulas sobre tais temas. Apesar de ele nunca ter falado explicitamente sobre algo como jogos de linguagem religiosos, podemos encontrar em suas obras alguns indícios que nos possibilitam defender a existência destes. Em primeiro lugar, cabe ressaltar o fato de que Wittgenstein nunca limitou o número de jogos de linguagem e nem mesmo a variedade e imprevisibilidade de regras que poderiam constituílos, ao contrário disso, deixou bem claro nas Investigações que não há um número limitado de jogos, mas que eles são infinitos e que novos jogos podem ser criados e outros desapareçam (WITTGENSTEIN, 2004, p. 27).

Ao enumerar a variedade de jogos de linguagem no parágrafo 23 das Investigações, Wittgenstein mostra que dentre eles, por exemplo, poderiam estar os atos de rezar, pedir e agradecer. Ora, isso nos dá a impressão de que ele admitia que o rezar é um jogo de linguagem plausível, com sentido, e que não é nem melhor nem pior em termos linguísticos do que o fato de ordenar e agir segundo ordens, ou outra qualquer atividade 
linguística. Nesta mesma perspectiva, em Aulas e Conversas sobre Fé religiosa, ele dará como exemplo a crença no Juízo Final como uma crença que tem sentido, ao menos para aqueles que nele creem. Ele se pergunta: "Porque não deveria uma forma de vida culminar na expressão de uma fé num Juízo Final?" (WITTGENSTEIN, 1993, p. 101). Mais do que isso, o que chama a atenção é que, além de se fazer tal questionamento, deixa bem claro que talvez não pudéssemos responder a tal crença da mesma forma que responderíamos a uma crença natural. Em nossa concepção, tal ideia nos mostra que o autor em questão, muito mais do que admitir a existência de um jogo de linguagem religioso, admite que ele possui regras.

Alguém poderia nos dizer que estamos inferindo jogos de linguagens científicos e religiosos, sendo que Wittgenstein nunca disse nada a respeito também da existência de um jogo de linguagem científico. Ora, ele nunca citou um conceito tal, mas deixa bem claro que na linguagem da ciência existem regras próprias que diferem de jogos de linguagem próprios de brincadeiras de crianças, por exemplo. Assim, não vemos como arbitrária tal colocação. Como bem o coloca Barrett, as linguagens da ciência possuem regras as quais são seguidas pelos cientistas e compõem uma prática muito maior. "A diferença entre os jogos de linguagem científicos está determinada pelas diferentes atividades nas quais participam os cientistas, os métodos que empregam e os objetivos que perseguem como cientistas que trabalham em um campo determinado" (BARRETT, 1994, p. 167).

Em nossa concepção, da mesma forma que na ciência, o jogo de linguagem está inserido na prática científica, também na religião, o jogo de linguagem está fixado em práticas próprias. Ao contrário da metafísica que é uma especulação sobre a linguagem, tentando fixar regras para além da prática da própria linguagem - a religião tem uma prática. O religioso se insere em ritos, expressões e vivências da religião e é aí que a linguagem ganha sentido. O que o religioso faz não é uma especulação sobre a linguagem religiosa, mas uma vivência e experiência desta linguagem. A linguagem religiosa começa a fazer sentido no momento em que o religioso começa a viver a religião. E, é dessa vivência da prática religiosa que surgem as regras e normas do jogo religioso, que o crente se dispõe a seguir.

Kay Nielsen discordaria profundamente de nós e diria que não há religião sem doutrina e que a doutrina é, por excelência, metafísica; portanto, não se pode defender a existência de jogos de linguagem religiosos. Ele cita o exemplo do Cristianismo, do Islamismo e do Judaísmo para corroborar sua tese. Segundo ele, no caso do cristianismo, as crenças 
metafísicas são claras e pode-se dar como exemplo as crenças na santíssima trindade e na eternidade de Deus. Ora, ele dirá, essas crenças são puramente metafísicas e se assim forem, o cristianismo é um sistema de crenças metafísicas (NIELSEN, 2004, p. 147). Mas, para Wittgenstein um sistema metafísico é incoerente, sendo assim, não haveria algo como um jogo de linguagem religioso. (NIELSEN, 2004, p. 161).

$\mathrm{Na}$ argumentação de Nielsen há, em nossa concepção, alguns equívocos. Em primeiro lugar, é preciso frisar que, para este autor, a visão de religião de Wittgenstein é uma visão reducionista, pois tomaria como algo religioso até mesmo ideias de pensadores tipicamente ateus. Tal argumentação surgiria do fato de Wittgenstein ter ligado a crença religiosa a ações e uma adesão apaixonada a um sistema de referências. Para Nielsen, tentar reduzir religião e crenças religiosas a algum comprometimento profundamente básico e a uma preocupação em ser um ser humano decente, para então preocupar-se com o outro e fazer o bem, sendo essas ações genuinamente religiosas, faz com que autores como Marx, Engels, Durkheim, entre outros, tornem-se todos religiosos (NIELSEN, 2004, p. 155).

A nosso ver, a visão reducionista de religião não é de Wittgenstein, mas do próprio Nielsen, que não consegue fugir dos emaranhados das religiões tradicionais e, mais do que isso, de uma visão filosófica sobre estas religiões. Nielsen parece estar sofrendo do problema de Frazer, que vê a religião somente sob a ótica do cristianismo inglês. Wittgenstein não estava preso a uma única visão de religião. Não podemos nos esquecer que ele já havia lido As Variedades da experiência religiosa de James. Além disso, se formos a fundo, veremos que para a maioria dos cristãos as crenças enumeradas por Nielsen não se constituem em crenças justificadas filosoficamente, mas como crenças a partir das quais eles agem e vivem, sem precisarem de explicações. Nessa perspectiva, é preciso frisar que, para Wittgenstein, quem entende essas crenças como metafísicas não é religioso, mas filósofo, e está doente de confusão gramatical. Lembremo-nos da citação sobre Santo Agostinho que fizemos anteriormente. Nela fica bem claro que o erro de Agostinho não foi proferir sua fé, mas a tentativa de teorizar sobre ela. Além do mais, dizer que creio na existência de uma vida futura não necessariamente é metafísica, mas pode ser uma forma de guiar minha vida, um princípio, regra ou norma que carrego comigo. Para Wittgenstein, o cristianismo não se reduz a uma doutrina, "não é uma teoria sobre o que aconteceu e virá a acontecer à alma humana, mas uma descrição de algo que na realidade ocorre na vida humana." 
(WITTGENSTEIN, 1996, p. 48). Quanto à possibilidade dos filósofos citados serem religiosos e suas teorias serem religiosas, Nielsen comete o erro de reduzir a religião a qualquer tipo de crença que guie a vida, e não parece ser isso que Wittgenstein defende.

Não se pode dizer que uma crença empírica ou da ciência não possa guiar a vida de alguém, é claro que pode, mas o detalhe está até onde ela pode guiar. Vasiliou, em seu artigo "Wittgenstein and Philosophy of Religion", faz uma diferenciação interessante sobre isso. Para ele, a crença empírica também pode mudar a vida, por exemplo, no caso de alguém que fica sabendo, pelo médico, que sua vida está prestes a acabar. Ele poderá mudar sua forma de viver, mas se depois de um tempo o médico disser que seu prognóstico foi um erro, sua vida volta ao normal. Para ele, a diferença entre a crença científica e religiosa está fundamentalmente na ideia de que a primeira necessita ser revista à luz de novas evidências, o que não acontece jamais com a crença religiosa, que é uma certeza absoluta (VASILIOU, 2001, p. 35-36). Da mesma forma, as crenças de Marx, Engels e outros precisam ser revistas à luz de novas teorias. Em contraposição a isso, as crenças religiosas mantêm-se firmes e não são subjugadas a descobertas novas. Ora, nessa mesma perspectiva, poderíamos questionar Nielsen, a la Wittgenstein, se foram as doutrinas de Aquino que fizeram com que ele cresse em Deus ou foi a crença em Deus que originou as doutrinas de Aquino. Para Wittgenstein:

\begin{abstract}
uma prova da existência de Deus deveria realmente ser algo por meio do qual alguém se poderia convencer a si mesmo de que Deus existe. Mas creio que aquilo que os crentes, que apresentaram tais provas, quiseram fazer foi fornecer à sua 'crença' uma análise intelectual e um fundamento, embora eles próprios nunca viessem a acreditar através de tais demonstrações. Talvez se pudesse 'convencer alguém de que Deus existe' mediante um certo tipo de educação, configurando sua vida de tal ou tal maneira (WITTGENSTEIN, 1996, p. 125).
\end{abstract}

Nesta passagem, fica bem claro que a religião que Wittgenstein está preocupado em entender não é uma teoria filosófica sobre as práticas religiosas, mas a própria prática religiosa.

$\mathrm{Na}$ mesma esteira de argumentação de Nielsen, encontramos John Hyman, que faz duras críticas à visão de religião de Wittgenstein. Dentre as críticas mais significativas, está uma que defende que as evidências e argumentações não são somente privilégio da ciência. Para tal autor, 
Wittgenstein não pode estar certo em insistir que se nós tentarmos provar ou justificar a proposição que Deus existe, nós estaremos já presos em confusões, porque nós estamos tratando religião como se ela fosse uma ciência. Eu penso que seria tolice manter que Anselmo e Aquino estivessem tratando de superstições ou que a apostasia não possa ser baseada sobre razões (HYMAN, 2001, p. 8).

O problema nas teorias de Aquino e Anselmo, a nosso ver, não se dá pelo fato que eles falem sobre religião, mas que eles façam metafísica com as crenças religiosas. Aquino, Anselmo e outros não se fixam na prática religiosa, ou seja, não descrevem as regras das práticas, o que eles fazem é tratar a religião como um problema filosófico e tentar encontrar os fundamentos desta a partir da filosofia e não a partir da prática religiosa. É aí que reside o erro de tais autores. Por outro lado, ao citar a apostasia e dizer que se pode dar razões para cometê-la, Hyman não se dá conta do dito wittgensteiniano que dar razões à religião é já deixar de ser religioso. $\mathrm{O}$ homem verdadeiramente religioso não sai em busca de razões para sua fé, mas basta-se em sua própria crença. Assim, talvez Wittgenstein invertesse o argumento de Hyman, dizendo que é por tentar dar razões à religião que se comete apostasia. Não se pode esquecer aqui o dito de Wittgenstein sobre o surgimento de novas religiões. Ele afirma: "Diz-se com frequiência que uma nova religião estigmatiza como diabos os deuses da velha religião. Mas na realidade eles já então se tinham, provavelmente, tornado diabos." (WITTGENSTEIN, 1996, p. 32). A apostasia surge no momento em que a religião já não faz mais sentido para o crente. As razões dadas a ela são da mesma estirpe daquelas dadas por Aquino a sua crença.

Em nossa concepção, a argumentação de Hyman sobre a religião está baseada em sua tese de que Wittgenstein nunca teria dito que na base da forma de vida não poderiam existir crenças metafísicas. Para Hyman, crenças metafísicas podem fazer parte de um jogo de linguagem e de uma forma de vida e utiliza o exemplo do cristianismo que tem em suas práticas várias crenças metafísicas. Nós discordamos de Hyman neste aspecto. $\mathrm{O}$ que ele não percebe é que Wittgenstein tenta nos livrar das confusões metafísicas e de que uma crença metafísica no interior de um jogo é uma tentativa de fundamentar tal jogo para além da prática do próprio jogo. A nosso ver, tal ideia vai totalmente contra as concepções e lutas que Wittgenstein emprega contra o fundacionalismo. Não se pode esquecer do dito presente já no Tractatus de que a linguagem cotidiana está em perfeita ordem. Na vida cotidiana, as crenças humanas não são crenças metafísicas 
e também não há uma busca por um fundamento último para a linguagem. No Da certeza, fica bem claro que as crenças não precisam de um fundamento último que seja metafísico. Em nossa concepção, o que Hyman confunde em sua argumentação é a religião cotidiana com uma teologia cristã baseada em metafísica. A pergunta que se faz a ele é se realmente um não-filósofo vê as crenças religiosas como metafísicas. Além disso, não podemos nos esquecer que para Wittgenstein o grande problema de se dar razões para a religião é a falta de parâmetros para comprovarmos essas razões. É isso que o faz dizer que para cada razão dada existiria uma contra-razão igualmente válida. (WITTGENSTEIN, 1996, p. 51).

Algo que parece ligar a crítica de Hyman e a de Nielsen à possibilidade de um jogo de linguagem religioso, parece ser a falta de reflexões sobre o problema da generalização em filosofia proposto por Wittgenstein no Livro Azul. Essa constatação surge do fato de em ambos os autores aparecer a necessidade de que toda e qualquer crença seja fundamentada. Aqui podemos citar Philips que, em seu artigo "Religious Belief and Language-games" mostra que o desejo de generalidade se mostra nitidamente na

[...] insistência, que o uso de 'existência' e 'crença' é o mesmo em todos os contextos, e (n)a dificuldade para reconhecer isto como uma elevação ilegítima de um uso destas palavras como um paradigma para qualquer uso das palavras. O que Wittgenstein mostra em suas anotações sobre crença religiosa é que há boas razões para observar os diferentes usos que 'crença' e 'existência' têm, e para resistir ao desejo de generalidade (PHILLIPS, 1993, p. 62).

Assim, em nossa concepção, os argumentos de Hyman e Nielsen são frutos de uma concepção filosófica de busca por fundamentos firmes e intocáveis, fundamentos estes que perpassariam toda a estrutura da linguagem. Ora, o que Wittgenstein mostra é que nem mesmo na religião haveria um único modo de se entender um conceito. Em Cultura e Valor ele reflete:

Como posso eu saber que duas pessoas se referem ao mesmo quando cada uma delas diz acreditar em Deus? E o mesmo se aplica à crença na Trindade. Uma teologia que insiste no uso de certas palavras e expressões particulares, proibindo outras, não torna nada mais claro (Karl Barth). Gesticula, por assim dizer, com palavras, porque pretende dizer algo e 
não sabe como o exprimir. A prática confere às palavras o seu sentido (WITTGENSTEIN, 1996, p. 125).

Ou seja, até mesmo na religião o que é preponderante é a prática religiosa e não as teorias filosóficas sobre ela.

Outro ponto de vista sobre a existência e natureza dos jogos de linguagem religiosos é apresentado por Margutti Pinto em A questão do sujeito transcendental em Wittgenstein. Ele faz uma análise da possibilidade de o jogo de linguagem religioso realmente deixar de lado a esfera indizível da religião presente no Tractatus. Tal autor concorda com a existência de um jogo de linguagem religioso, porém, para ele "O jogo de linguagem religioso pretende significar algo diferente do usual e, para atingir este objetivo, enfatiza, por exemplo, as reações das pessoas" (MARGUTTI PINTO, 2006, p. 19). Sendo algo diferente do usual, ele não conseguiria expressar em plenitude valores absolutos, próprios da vida religiosa. Para chegar a essa conclusão, ele utiliza o exemplo da palavra "crer", que na religião não seria uma palavra utilizada na forma ordinária. Sendo assim, o critério para significar algo não estaria somente na palavra, mas na evidência, na reação das pessoas.

Tal autor faz uma distinção entre aquilo que é contingente e o que é transcendental, colocando os valores religiosos na esfera do transcendental, usando assim de uma divisão tipicamente tractatiana. Tal ideia está baseada no pressuposto de que o pensamento de Wittgenstein não pode ser entendido sem a compreensão de sua postura ético-religiosa. Para ele,

os jogos de linguagem admitidos pela segunda filosofia se referem a manifestações contingentes numa dada forma de vida, não alcançando a região dos valores transcendentais, aqueles que realmente importam. Nesse caso, seria válida não só na primeira, mas também na segunda filosofia de Wittgenstein, a declaração do prefácio do Tractatus, segundo a qual se procura mostrar como importa pouco resolver os problemas ligados aos limites da linguagem. Com efeito, a solução do problema do sentido da vida não se encontra na determinação desses limites, que nos ensinam apenas o que pode e o que não pode ser dito. O sentido da vida é obtido através de uma experiência de caráter místico. Uma vez alcançada esta experiência, a determinação dos limites da linguagem só auxilia na constatação de que o conteúdo experienciado não pode ser colocado em palavras (MARGUTTI PINTO, 2006, p. 21).

Nesta passagem mostra-se claramente a profunda ligação que Margutti vê entre as visões da primeira obra de Wittgenstein e a segunda. 
Para Margutti, então, os jogos de linguagem religiosos existem, mas eles possuem limites de alcance para aquilo que é religioso, ou melhor, eles não expressam tudo o que a religião significa. Ele afirma:

embora haja inúmeros jogos de linguagem de caráter religioso, todos eles pertencem a formas de vida contingentes. Os valores envolvidos não são transcendentais, mas relativos, porque até mesmo a linguagem pública não é capaz de exprimir algo mais elevado. [...] Portanto, até mesmo nas Investigações vale a constatação de que, embora exista algo profundamente importante em nossas vidas, esse algo não pode ser colocado em palavras e deve ser contemplado em silêncio (MARGUTTI PINTO, 2006, p. 24).

Em nossa concepção, as ideias de Margutti se equivocam em alguns aspectos fundamentais para o entendimento da filosofia da linguagem de Wittgenstein e também na compreensão de sua perspectiva de religião. Em primeiro lugar, Margutti parece ter se equivocado com o conceito de 'uso' em Wittgenstein e ter entendido que haveria um uso ordinário e outro uso que se colocaria numa esfera superior à prática da linguagem. Quando Wittgenstein fala que a palavra crença é usada de modo diverso do que comumente utilizaríamos, ele apenas está descrevendo diferentes usos desta palavra, mas em ambas as utilizações, em nenhum momento o autor austríaco coloca em dúvida que tal uso é diferenciado simplesmente porque pertencem a práticas diversas. Assim, não seria necessário uma experiência mística para compreender o que o religioso entende por crer, mas simplesmente olhar para a gramática desta palavra. Para Wittgenstein, dizer que as expressões religiosas são diferentes das expressões comuns ou da ciência, é simplesmente dizer que pertencem a uma prática diferente. Ora, não podemos nos esquecer do fato que para ele aprendemos também os usos das palavras religiosas e as aprendemos de um modo diferente do uso de palavras cotidianas. É isso que ele defende ao dizer que aprendemos a palavra "Deus" de uma forma diferente do que aprendemos outras palavras.

A palavra 'Deus' é das palavras aprendidas mais cedo - imagens e catecismos, etc. Mas não com as mesmas conseqüências dos retratos de tias. [...] A palavra é usada como uma palavra que representa uma pessoa. Deus vê, recompensa, etc. 'Ao lhe serem mostradas todas essas coisas, compreendeu aquilo que a palavra significava?' Eu diria: 'Sim e não. Aprendi aquilo que não significava. Fiz-me compreender. Podia 
responder a perguntas, compreender perguntas quando eram colocadas de modos diferentes - e nesse sentido pode dizer-se que compreendi' (WITTGENSTEIN, 1993, p. 106).

O que queremos dizer é que o conceito de uso não tem um caráter especial, ele não está fora da prática. Ao dizer que usamos uma palavra, por exemplo, a palavra "crença", de forma diferente em diferentes circunstâncias, Wittgenstein apenas estava frisando os diferentes usos em diferentes jogos de linguagem.

Por outro lado, na leitura que Margutti faz da segunda filosofia da linguagem de Wittgenstein existiria ainda o indizível, pelo menos é isso que soa na interpretação de que os jogos de linguagem se referem ao contingente. O problema nessa interpretação é que não parece que Wittgenstein tenha pensado algo para além do contingente mundo da linguagem, ele não pressupõe isso. A profundidade da linguagem se encontra na própria linguagem, ou seja, em sua complexa gramática. Wittgenstein teria abandonado a ideia de que haveria uma esfera transcendental para a linguagem e qualquer outra coisa. Nessa mesma perspectiva, entendemos que os valores absolutos são apreendidos como absolutos, fazem parte de um jogo ou de um sistema de referência ao qual nos apegamos apaixonadamente e não o questionamos. O "indizível" aqui se refere somente à impossibilidade de uma filosofia tentar fundamentar os jogos. Além disso, Margutti parece pressupor que Wittgenstein teria limitado a linguagem ou o número de linguagens possíveis. Ora, isso parece contrariar em muito suas ideias de que há infinitos jogos de linguagem. $\mathrm{O}$ único limite que Wittgenstein parece discutir é o de respeito às regras dos diferentes jogos, evitando o entrecruzamento deles.

Ligado a isso, Margutti sugere, ao dizer que toda a linguagem se refere a formas de vida contingentes, a existência de uma forma de vida que teria um caráter especial ou mais explicitamente a existência de algo para além da linguagem que não pode ser explicado com a linguagem e é aí que estariam localizados os valores. A ideia é análoga à concepção de um sujeito volitivo tractatiano, ou seja, Margutti defende que, mesmo póstractatus, Wittgenstein estaria defendendo a existência de uma espécie de sujeito volitivo. Mais do que isso, ele sugere a existência de um solipsismo que seria responsável pela contemplação mística dos valores. Em nosso entender, se ele está defendendo a inexpressabilidade de valores absolutos e que esses só são acessados por meio de uma experiência mística, ele 
poderia estar se comprometendo com um certo solipsismo na segunda obra de Wittgenstein. Se é assim, temos um grande problema a ser resolvido, que é justamente as críticas de Wittgenstein à linguagem privada. Em nossa concepção, nem mesmo experiências privadas ou interiores, como a experiência mística, seriam inexpressáveis. Nossa defesa nasce do parágrafo 256 das Investigações, no qual Wittgenstein (2004) relata:

O que acontece então com a linguagem que descreve minhas vivências interiores e que só eu mesmo posso entender? Como designo minhas sensações com palavras? Como de costume? As palavras de minhas sensações se acham ligadas, portanto, às expressões naturais de minhas sensações? Neste caso minha linguagem não é 'privada'. Uma outra pessoa seria capaz de compreendê-la como eu. - E se eu não tiver expressões naturais da sensação, mas somente a sensação? Eu associo então, simplesmente, nomes às sensações e emprego estes nomes numa descrição.

Nessa passagem fica bem claro que mesmo se não tivermos nenhuma expressão natural para determinada sensação ou experiência, podemos descrevê-la para que outro entenda, apenas explicando o uso das palavras que estou utilizando. Associo nomes, explico os usos destes nomes e passo minha experiência. Isso fica bem claro no exemplo do besouro dentro de uma caixa, presente no parágrafo 293 das Investigações:

Suponhamos que cada um tivesse uma caixa na qual estivesse algo a que chamamos 'besouro'. Ninguém pode olhar dentro da caixa do outro; e cada um diz saber o que é um besouro apenas a partir da vista do seu besouro. - Entretanto, poderia ser que cada um tivesse uma coisa diferente em sua caixa. Sim, poder-se-ia imaginar que tal coisa se modificasse continuamente. - Mas, e se a palavra 'besouro' dessas pessoas tivesse esse uso? E não seria usada como designação de uma coisa. A coisa na caixa não pertence absolutamente ao jogo de linguagem; nem mesmo como algo: pois a caixa poderia também estar vazia. - Não, pode-se 'abreviar' por meio desta coisa na caixa; elimina-se, seja o que for.

Isto quer dizer: se construímos a gramática das expressões de sensação segundo o modelo de 'objeto e designação', então o objeto fica fora de consideração como irrelevante.

O que importa não é se o besouro está ou não na caixa, ou o que as pessoas veem como besouro, mas a gramática dessa palavra. Da mesma forma, poderíamos dizer que o que importa para a filosofia que se preocupa 
com a religião é a gramática dela. Ao que parece, Wittgenstein não considera, em sua segunda filosofia da linguagem, a possibilidade da existência de algo inexpressável pela linguagem e pensar o contrário se constitui num equívoco.

Antes de irmos adiante é preciso frisar outro problema presente na discussão da possibilidade ou não de um jogo de linguagem religioso, a saber, o problema de se este jogo seria totalmente independente de outros jogos. Nessa discussão está presente a possibilidade ou não da relação entre jogos de linguagens diferentes e como a religião se comportaria dentro da teia da linguagem formada por inúmeros jogos. Tal problema surge por Wittgenstein ter apresentado certa impossibilidade de diálogo entre o crente e o não crente. D. Z. Philips tem uma posição interessante sobre isso, e que concordamos. Para ele, sem dúvida o jogo de linguagem religioso é independente, mas pregar sua independência não o exclui da rede total da linguagem; ele não se torna, portanto, um jogo esotérico à linguagem como um todo. Para ele, dizer que as "reações religiosas a várias situações não podem ser acessadas de acordo com critérios externos de adequação" (PHILLIPS, 1993, p. 70) e que, por outro lado, há uma relação entre as crenças religiosas e tais situações reais, não seria contraditório. A força e significado da religião dependem muito da existência de outras faces da vida humana que não são religiosas.

O problema é que alguém poderia dizer que essa relação do crente com outras esferas da vida que não são religiosas provaria que não existe um jogo de linguagem religioso independente, mas que ele seria parte integrante de outros jogos ou, na pior das hipóteses, um jogo totalmente desnecessário na vida humana. Phillips responde a essa objeção dizendo que os filósofos que pensam dessa forma estão caindo em confusão, pois o que eles buscam provar é que os fatos ou situações não-religiosas seriam a justificação para as crenças religiosas. Vejamos o que Phillips escreve:

Tendo reconhecido, corretamente, que o significado da crença religiosa é parte dependente de outras faces da vida humana para além da religião, os filósofos concluem, erradamente, que alguém poderia contradizer-se se reivindicasse reconhecer essa dependência, e também que as crenças religiosas são jogos de linguagem distintos. Eles são levados a essa conclusão somente porque assumem que a relação entre crenças religiosas e fatos não-religiosos é a mesma que entre o que é justificado e sua justificação, ou entre uma conclusão e seus argumentos. Isto é uma confusão. Dizer que o significado da crença religiosa é parcialmente dependente de fatos não religiosos não é dizer que aquelas crenças são 
justificadas por estes, ou poderiam ser inferidas destes fatos em questão (PHILLIPS, 1993, p. 67)

Para justificar suas ideias, Phillips lança mão de vários exemplos que mostram a diferença entre uma crença religiosa e uma simples crença factual, como a superstição, na qual a fé é simplesmente um meio para atingir determinado fim; ou seja, me utilizo de um ritual ou de uma crença como forma para atingir determinada coisa em minha vida, e a crença está condicionada a que essas coisas aconteçam ou não (PHILLIPS, 1993, p. 72-73). O que Phillips mostra, e nós concordamos, é que a linguagem religiosa é parte integrante da vida social humana, mas se distingue de outros jogos por ter regras próprias a ela e que precisam ser elucidadas se realmente se quer conhecer tal jogo. Se pensarmos que o que Wittgenstein combate é o entrecruzamento de jogos, no qual um jogo tenta fundamentar os outros com suas regras, veremos que ele não queria dizer que um jogo deve se isolar de outros jogos, mas que há particularidades em cada jogo que precisam ser respeitadas.

Com o que fizemos até aqui, é possível darmos um salto e apresentarmos rapidamente algumas ideias de como Wittgenstein entende os jogos de linguagens religiosos.

\section{Fé e linguagem: a compreensão dos jogos religiosos}

Discutimos, na seção anterior, a possibilidade ou não da existência de jogos de linguagem religiosos, mostrando que, na filosofia pós-Tractatus, Wittgenstein dá pistas que nos fazem intuir a existência de linguagens tipicamente religiosas e que teriam um sentido, compondo um conjunto diverso de jogos. Porém, o que nos falta no momento é discutir com mais profundidade qual seria a gramática desses jogos, ou seja, quais são as regras, atividades e conceitos que estão presentes em tais jogos? E, mais do que isso, como tais jogos podem ser compreendidos?

Para Wittgenstein, quando temos fé, ou seja, quando jogamos um jogo religioso, somos capazes de arriscar nossas próprias vidas, estamos apaixonadamente agarrados a um sistema de referência e esse sistema guia toda a nossa vida, apesar de não termos nenhuma explicação razoável para ele. Ou seja, por mais absurdo que possa parecer, o crente religioso agarra-se ao sistema conceitual da religião a que pertence e nenhuma 
explicação científica o pode fazer voltar atrás. Nesse sentido, Wittgenstein dirá em Cultura e Valor que o cristianismo não deve tentar provar suas crenças, mas dizer "creia, por mais absurdo que vos pareça!"1. Ao dizer que a crença religiosa é absurda, ele não está menosprezando a religião, mas apenas dizendo que ela não pertence a um campo onde as coisas têm uma explicação racionalmente aceita, onde todos os argumentos fecham um com o outro e existem provas para todas as coisas.

Wittgenstein não é o primeiro filósofo a tratar a religião como um absurdo ou a fé como algo inexplicável. Não se pode esquecer da grande contribuição que Kierkegaard faz a esse tema e do quanto o primeiro é influenciado por este. Para Kierkegaard a fé extrapola todos os limites da razão, sendo um absurdo do ponto de vista racional. Na obra Temor e Tremor, ao descrever a história de fé de Abraão, ele defende que nenhuma explicação racional poderia justificar o ato do patriarca sacrificar o próprio filho. Se tentássemos explicar do ponto de vista racional, cairíamos na esfera moral e consideraríamos Abraão um assassino ou um louco; somente visto como um ato de fé ele ganha um sentido. Isso não quer dizer que o patriarca não fizesse uso de sua razão. Ao contrário, é justamente por fazer uso da razão e se angustiar perante seu ato que a atitude de Abraão ultrapassa a esfera da razão. Kierkegaard nos diz:

Se a fé não pode santificar a intenção de matar o filho, Abraão cai sob a alçada dum juízo aplicável a todo mundo. [...] Sob o ponto de vista moral, a conduta de Abraão exprime-se dizendo que quis matar Isaac e, sob o ponto de vista religioso, que pretendeu sacrificá-lo. Nesta contradição reside a angústia que nos conduz à insônia e sem a qual, entretanto, Abraão não é o homem que é. [...] Quando, na verdade, se suprime a fé, reduzindo-a a zero, resta só o fato brutal de Abraão ter querido matar o filho, conduta bem fácil de imitar por quem não possua fé - entendo eu por fé o que torna difícil o sacrifício (KIERKEGAARD, 1979, p. 125).

A crença aqui nada mais é do que uma esperança num absurdo. Fazendo uso de nossa razão, nos perguntaríamos como é possível que

WITTGENSTEIN, 1996. Não podemos nos furtar do fato que esta ideia de absurdo está presente de forma clara na doutrina paulina. São Paulo, na carta aos Coríntios, dirá que não se pode explicar de nenhuma forma a ressurreição de cristo, que ela é um absurdo e justamente por ser um absurdo é que devemos crer com todo nosso coração. 
haja um Deus tão maligno capaz de dar um filho, enchendo de esperança o já velho Abraão, e depois tirá-lo por um simples capricho de sua vontade? Por outro lado, como pode Abraão aceitar tão resignadamente a vontade divina e não questioná-la? Kierkegaard responde esta questão dizendo que isso só é possível depois de uma resignação infinita.

A resignação infinita é o último estádio que precede a fé, pois ninguém a alcança antes de ter realizado previamente esse movimento; porque é na resignação infinita que, antes de tudo, tomo consciência de meu valor eterno, e só então se pode alcançar a vida deste mundo pela fé (KIERKEGAARD, 1979, p. 135).

Neste mesmo sentido ele afirma que depois do movimento de resignação, ao perceber que não atingirá, pelas suas forças, o que deseja, o cavaleiro da fé diz:

Eu creio, sem reserva, que obterei o que amo em virtude do absurdo, em virtude da minha fé de que tudo é possível a Deus. O absurdo não pertence às distinções compreendidas no quadro próprio da razão. Não se pode identificar com o inverossímil, o inesperado, o imprevisto. [...] O cavaleiro da fé tem também lúcida consciência desta impossibilidade; só o que o pode salvar é o absurdo, o que concebe pela fé. Reconhece, pois, a impossibilidade e, ao mesmo tempo, crê no absurdo; porque, se alguém imagina ter a fé sem reconhecer a impossibilidade de todo o coração e com toda a paixão da sua alma, engana-se a si próprio e o seu testemunho é absolutamente inaceitável, pois que nem sequer alcançou a resignação infinita (KIERKEGAARD, 1979, p. 136).

O movimento da fé proposto pelo filósofo é um movimento que pressupõe um salto no absurdo. Uma crença de que nada, nem ninguém, nesse mundo é capaz de dar as respostas que o ser humano procura. Tais respostas podem ser absurdas do ponto de vista mundano, mas são plenas de sentido do ponto de vista religioso.

O movimento da resignação à fé é também muito bem descrito por Spengler, em A decadência do Ocidente. O autor mostra que a religião pressupõe um aniquilamento da própria existência para atingir certa renovação.

Chamamos de religião a consciência vigilante de um ser vivo nos momentos em que ele vence, domina, nega, e mesmo aniquila a 
existência. A vida racial e o ritmo dos seus impulsos tornam-se pequenos e mesquinhos em face da perspectiva imensa do mundo dilatado, extenso, luminoso (SPENGLER, 1982, p. 346).

O que parece acontecer é justamente uma ideia de que a fé religiosa traz com ela uma nova forma de ver e entender a realidade. Entender e compreender a vida como um todo. Mas isso só seria possível através de uma fé profunda, ou seja, uma fé capaz de mudar a própria vida e todo seu significado.

Wittgenstein parece concordar com essa ideia e dirá que a crença religiosa modifica a vida como um todo e isso é uma das coisas que a diferencia da crença científica. A primeira é uma crença absoluta que torna o sujeito capaz até mesmo de dar a própria vida. Em muitos momentos, em Cultura e Valor, mostra-se que a fé não está baseada em evidências científicas ou de caráter comum. A crença religiosa deixa de lado toda e qualquer justificativa racional:

A religião diz: Faz isto! - mas não pode justificar isto e, se o tentar sequer, torna-se repelente; porque para cada razão que apresenta há uma contra-razão válida. É mais convincente dizer: 'Pensem assim! Por mais estranho que vos parecer'. Ou: 'Não queres fazer isto? Por mais repugnante que seja'. (WITTGENSTEIN, 1996, p. 51).

O filósofo em questão parece radicalizar esta ideia ao dizer que é necessário que a fé não seja especulativa. A fé surge de uma necessidade humana diante do mundo e da vida e a resposta a essa necessidade, a resposta ao desespero de que o mundo não vai me dar o que procuro, é o que faz com que eu necessite de uma certeza inabalável, uma crença absoluta:

E a fé é a fé naquilo de que necessita o meu coração, a minha alma, e não a minha inteligência especulativa. Pois é a minha alma com as sua paixões, por assim dizer, com a sua carne e sangue, que têm de ser salva, e não a minha razão abstrata. [...] O que combate a dúvida é, por assim dizer, a redenção. A adesão a ela deve ser a adesão a esta crença. Assim, o que tal significa é: deves, primeiro, ser redimido e apoiar-te na tua redenção - em seguida verás que te estás a agarrar a esta fé: mas tal só pode acontecer se o teu peso já não assentar na terra, mas se te suspenderes do céu. Então tudo será diferente e não será de espantar que possas fazer coisas que agora não podes fazer (WITTGENSTEIN, 1996, p. 56). 
Assim, a fé não é uma necessidade especulativa, mas uma necessidade que nasce de um sentimento diante do mundo e da vida. A fé religiosa não é um jogo de perguntas e respostas, de acertos e erros, mas um jogo de certezas. Certezas estas que estão na base de um modo de viver, de uma forma de encarar a vida e o mundo. Essa forma de encarar a vida e o mundo é descrita pela doutrina religiosa como a forma correta de viver, a maneira certa de olhar os fatos do mundo e da vida, mas só será assim se fizer sentido para o crente.

Leio: 'ninguém pode dizer que Jesus é o Senhor a não ser através do Espírito Santo.' - É verdade: não posso chamar-lhe Senhor; porque tal não me diz nada. Poderia chamar-lhe 'o modelo ideal', até mesmo Deus; ou antes, quando ele assim é chamado, consigo compreendê-lo; mas não consigo pronunciar a palavra 'Senhor' com sentido. Porque não acredito que ele virá julgar-me; porque isso nada me diz. E só poderia dizer-me algo se vivesse de um modo completamente diferente (WITTGENSTEIN, 1996, p. 55).

Nessa passagem mostra-se claramente que a relação do crente com as sentenças religiosas é uma relação diferenciada de uma relação diante de sentenças empíricas. Nas primeiras há uma relação afetiva, de necessidade que o que esteja sendo dito realmente faça algum sentido para o todo da minha vida, para a minha existência. A fé se coloca como guia para minha vida, ela define todas as minhas atitudes diante da vida, formam a imagem a partir da qual eu compreendo minha existência. Não é o significado como correspondência que importa, não é a verdade. O que interessa é o que as palavras religiosas dizem para o crente. Essa ideia é muito bem trabalhada por Phillips que utiliza um exemplo interessante que traremos aqui. Ele faz um paralelo com o Górgias de Platão que é, a nosso ver, uma colocação perfeita de como Wittgenstein entende a crença religiosa. Ele diz:

Polus não entende Sócrates quando o último diz que a bondade é uma vantagem para o homem. Ele aponta Archelaus o tirano da Macedônia. Sem dúvida, ele foi um mau homem que prosperou. Não é fácil qualquer criança mostrar que Sócrates estava errado? Mas a falácia no argumento de Polus é sua suposição que ele e Sócrates podem somente significar algo quando eles falam de prosperidade. [...] Para Sócrates, contudo, não é a visão mundana de prosperidade que determina o que é bom, mas o que é bom que determina o que conta como prosperidade (PHILLIPS, 1993, p. 60). 
Para Phillips, muitos intérpretes da religião a interpretam como Polus, colocando a fé em Deus como submissa às coisas do mundo. Mas o que acontece realmente com o crente é o contrário. Não é sua visão do mundo que determina sua visão de Deus, mas a crença em Deus que determina toda a sua visão de mundo, ou nas palavras do próprio Phillips, "a fé em Deus que determina o que é considerado vitória” (PHILLIPS, 1993, p. 60).

O conceito de fé utilizado pelo filósofo em questão se aproxima de uma paixão inexplicável do ponto de vista racional. Tal paixão é um agarrarse profundamente a um sistema de referências e nele permanecer. Nessa ideia também aparece de forma contundente a influência de Kierkegaard. Este, ao comentar o ato de Abraão, diz que ele necessita de paixão. "Para tanto é necessário paixão. Todo o infinito se efetua apaixonadamente; a reflexão não pode produzir qualquer movimento. É o salto perpétuo na vida que explica o movimento." (KIERKEGAARD, 1979, p. 133). Um movimento não racional, mas apaixonado, que leva consigo toda uma concepção de vida parece ser a grande característica do conceito de fé de Wittgenstein. A fé está ligada a uma concepção de viver, a uma prática de vida.

Aqui se reflete a ideia de que a fé religiosa vem acompanhada de uma mudança na maneira de ver e entender a realidade. O filósofo afirma: "Surpreende-me que uma crença religiosa possa ser apenas algo idêntico a uma decisão apaixonada por um sistema de referência. Pois, embora seja crença, é, na realidade, um modo de vida, ou um modo de avaliar a vida. É uma apreensão apaixonada desta concepção". (WITTGENSTEIN, 1996, p. 97). Nessa passagem, Wittgenstein mostra que a fé religiosa é uma decisão de seguir certo sistema de referência, um conjunto de ideias e conceitos que guiariam a vida. Essa decisão apaixonada por um sistema de referências não pode ser uma mera crença, mas uma forma de viver.

Diante disso, podemos afirmar que o filósofo utiliza o ter fé não como uma crença qualquer, mas como uma crença absoluta que modifica a vida daquele que a possui e guia suas ações cotidianas. É nessa perspectiva que não há uma separação entre a fé e a vida. A vida guia-se pelo sistema de referência da doutrina em que se acredita. Um homem de fé é reconhecido não pelas palavras que ele fala, mas pela vida que ele leva. Ele afirma: "Creio que uma das coisas que o Cristianismo afirma é que as boas doutrinas são todas inúteis. Importa, sim, mudar a vida (ou a direção de tua vida)." (WITTGENSTEIN, 1996, p. 82). A fé religiosa, assim, mostra-se como uma prática de vida, uma maneira de viver e entender a vida. E essa crença não está ligada a fatos cotidianos e 
passageiros, mas a certezas e conceitos absolutos. Diante da crença religiosa, o crente não se coloca como investigador de causas e consequências, mas de forma afetiva, como alguém que necessita do absoluto diante da contingência do mundo que o cerca. Mas qual é a linguagem dessa forma de ver o mundo? Como podemos compreender essa maneira de ver a vida?

Talvez para respondermos a essas questões tenhamos que voltar rapidamente às anotações sobre Frazer e, a nosso ver, buscar apoio nas ideias que Wittgenstein desenvolve em sua última obra, a saber, o $D a$ Certeza. Nas anotações sobre Frazer, Wittgenstein combate o tom imperialista do intelectualismo frazeriano em que o primitivo é descrito para todos os efeitos como um palhaço ridículo, algo simplório perdido em um mundo que ele não pode nem controlar nem entender. Mas, o perigo disso é então cairmos num expressivismo barato que diria que toda religião é composta de crenças injustificadas, ou que a linguagem da religião é meramente expressão de nosso sentimentos interiores, não tendo nada a ver com seres racionais. Mas será que Wittgenstein realmente entende a religiosidade de um modo expressivista.

Para Clack, seria equivocado entender os pensamentos de Wittgenstein como expressivistas. Há razões e teses que nos fazem perceber isso. A primeira é externa às anotações sobre Frazer e a segunda coloca-se ante seus comentários sobre a magia. Para tal autor, "seria bizarro que Wittgenstein abraçasse uma teoria da religião que fosse incompatível com seu projeto filosófico como um todo." (CLACK, 2001, p. 21). Concordamos com Clack, em sua tese, pois seria estranho Wittgenstein ter ideias sobre religiosidade contrárias por exemplo, ao seu combate à ideia de linguagem privada, à sua percepção de que todo pensamento é já linguagem e que esta não é meramente veículo de transporte de emoções, sentimentos e pensamentos. Além disso, a tese expressivista reforça uma visão particular de significado e reforça, ainda, uma distinção acentuada entre o descritivo e o não descritivo que é igualmente rejeitada por ele (WITTGENSTEIN, 2004, p. 27-28). Para Wittgenstein, esse excesso de dupla dicotomia - o descritivo-não-descritivo, cognitivo-não-cognitivo, crença-atitude, explanação-expressão - seria redundante, e fruto de uma má compreensão da gramática da linguagem.

Wittgenstein está implacavelmente "em oposição ao intelectualismo - não porque ele tenha uma compreensão instrumentalista do ritual, mas porque ele é excessivamente racionalista, porque ele entende 
que todos os rituais são produtos do raciocínio" (CLACK, 2001, p. 23). É, ao contrário, uma tentativa de sugerir que práticas religiosas e mágicas não são o resultado de algum esforço teórico ou explicativo de um elemento do ser-humano, mas isso não necessariamente leva a um expressivismo. Não se pode esquecer que no Da Certeza, o filósofo mostra que somente bem mais tarde na vida buscamos explicar a existência ou inexistência das coisas com as quais lidamos durante toda a nossa vida. Não aprendemos que existem canetas, mas sim a desempenhar atividades que envolvem canetas (WITTGENSTEIN, 1990, p. 159). O que Wittgenstein parece propor é que devemos entender a religiosidade como um tipo de saber, um saber que se diferencia de saberes teóricos ou empíricos. O problema do intelectualismo é justamente o de achar que tudo se reduz a um único campo de saber, a uma única forma de ver e entender o mundo.

Wittgenstein quer chamar nossa atenção para o fato de que a vida humana é mais intensa e colorida que um mero racionalismo: ela é regrada pela paixão, pelo instinto, por motivações que nós podemos descobrir e agarrar, por práticas sociais que nos envolvem e enchem nossa existência de sentido. Mais do que isso, que muito de nossos conceitos são formados a partir de práticas que não envolvem uma reflexão ou teorização.

Assim, o que Wittgenstein propõe é que não devemos generalizar nosso entendimento sobre a religião; não devemos olhá-la nem sob o aspecto de um racionalismo nem sobre o aspecto de um expressivismo que já vem poluído por uma ideia racionalista de que, enquanto expressivismo, ela não tem nada a nos dizer. $\mathrm{O}$ que ele propõe então é que nos fixemos a olhar a própria prática religiosa, "olhe... não pense", e então será possível compreendê-la. A religião parece ser apenas mais uma das várias maneiras da linguagem humana se relacionar com o mundo. Os problemas surgem quando tiramos as sentenças religiosas de seu campo e queremos jogar com elas um outro tipo de jogo, como se quiséssemos jogar futebol com as regras do tênis

\section{CONSIDERAÇÕES FINAIS}

Buscamos, neste trabalho, fazer uma breve análise sobre a possibilidade e peculiaridades de jogos de linguagem religiosos. Num primeiro momento, apresentamos a possibilidade destes jogos serem defendidos dentro da obra de Wittgenstein, discutindo com alguns de seus 
intérpretes. Mostramos que a linguagem religiosa não é uma linguagem metafísica por possuir uma prática e estar ligada a uma forma de vida, assim ela seria uma linguagem com sentido, pública e de total compreensão. Por outro lado, ela é uma linguagem independente, com características próprias que a diferencia de jogos de linguagens empíricos ou científicos.

Num segundo momento, ativemo-nos numa discussão sobre algumas características que Wittgenstein atribui à religião, mostrando que ela é uma linguagem que desempenha um papel na busca pelo sentido da existência, sendo essa a principal característica que a diferencia da ciência. Com isso, discutimos o fato de que a religião deve ser compreendida de acordo com suas regras e que não devemos tentar compreendê-la nem com as regras da ciência como o fez Frazer, nem como uma linguagem expressivista que nada tem a nos dizer e vai contra toda a luta de Wittgenstein. Se assim o fizermos, perderemos o que a religião tem de mais interessante para a vida humana.

Nosso objetivo era dar algumas contribuições referentes às anotações de Wittgenstein sobre a religião. Esperamos ter cumprido um pequeno caminho neste trabalho, mas temos consciência de que muitas outras coisas ficaram para ser explicadas. Mas o mais importante é ressaltar a importância que Wittgenstein dá, em toda a sua filosofia, a outros saberes, diferenciados do saber científico.

\section{REFERÊNCIAS}

BARRET, C. Ética y creencia religiosa en Wittgenstein. Tradução de Humberto Marraud González. Madrid: Alianza, 1994.

CLACK, B. R. Wittgenstein and magic. In: ARRINGTON, R. L.; ADDIS, M. (Org.). Wittgenstein an philosophy of religion. New York: Routledge, 2001. p. 21.

HELM, P. Wittgenstein religion and 'reformed' epistemology. In: ARRINGTON, R. L.; ADDIS, M. (Org.). Wittgenstein an philosophy of religion. New York: Routledge, 2001.

HYMAN, J. The gospel according Wittgenstein. In: ARRINGTON, R. L.; ADDIS, M. (Org.). Wittgenstein an philosophy of religion. New York: Routledge, 2001. p. 8.

KIERKEGAARD, S. Temor e tremor. São Paulo: Abril Cultural, 1979. (Os pensadores). 
MORENO, A. R. Introdução a uma pragmática filosófica: de uma concepção de filosofia como atividade terapêutica a uma filosofia da linguagem. Campinas: Ed. da Unicamp, 2005.

NIELSEN, K. Wittgenstein and Wittgensteinians on religion. In: ARRINGTON, R. L.; ADDIS, M. (Org.). Wittgenstein an philosophy of religion. New York: Routledge, 2001.

PHILLIPS, D. Z. Wittgenstein and religion. London: Macmillan, 1993.

PINTO, P. R. M. A questão do sujeito transcendental em Wittgenstein. In: MORENO, A. R. (Org.). Wittgenstein: ética, estética, epistemologia. Campinas: Ed. da Unicamp, 2006. p. 19-24.

SPENGLER, O. A decadência do ocidente. Rio de Janeiro: Zahar, 1982.

VASILIOU, I. Wittgenstein, religious belief, and on certainty. In: ARRINGTON, R. L.; ADDIS, M. (Org.). Wittgenstein an philosophy of religion. New York: Routledge, 2001. p. 35-36.

WITTGENSTEIN, L. Über Gewiâheit = da certeza. Lisboa: Edições 70, 1990.

. Aulas sobre Fé Religiosa. In: WITTGENSTEIN, L. Aulas e conversas sobre estética, psicologia e fé religiosa. Lisboa: Cotovia, 1991.

Observaciones a la rama dorada de frazer. Madrid: Tecnos, 1992.

Tractatus logico-philosophicus. São Paulo: EDUSP, 1993.

Cultura e valor. Lisboa: Edições 70, 1996.

Investigações filosóficas. Petrópolis: Vozes, 2004.

Recebido: 10/12/2008

Received: $12 / 10 / 2008$

Aprovado: 04/03/2009

Approved: 03/04/2009 